\title{
Serials Price Increases Strive for Record Highs: "Globalization" a Factor
}

\section{Ann Okerson}

In early spring of 1990 , various serial subscription agencies predicted price increases in the region of $20 \%$ for 1991 . Hindsight shows these predictions to have been optimistic, given information released in early August by the New York offices of Elsevier Science Publishers and Springer-Verlag. For the Dutch firm, price increases converted to U.S. dollars will be as high as $35 \%$. A critical factor is decline of the dollar, which was 2.18 to the guilder last summer and at the end of July 1990 reached a low of 1.78 , a drop of about $22 \%$. Growth in journal size accounts for another $5.8 \%$ and publishing cost increases for $5.6 \%$. Libraries will bear similar increases for Elsevier's Swiss and French titles, and about $20 \%$ for British journals, where the exchange drop has been less severe.

Springer's increases for German titles will approach $26 \%$, of which more than $16 \%$ is dollar drop. Springer's domestic (U.S.) titles are expected to increase 10$11 \%$, reflecting a mix of expansion, higher production costs, and postal hikes. While other major international publishers were not available for comment, the announcements by Elsevier and Springer-Verlag are a powerful indicator of 1991 trends as the highest increases in recent years. Such increases have a staggering impact on library collections, particularly in the sciences, because U.S. research libraries purchase about $60 \%$ of their scholarly materials from abroad. In addition to high foreign prices, there is the real possibility that U.S. library postal rates may increase as much as $40 \%$, which will also affect subscription prices. Domestic price increases for 1991 are expected to be under $10 \%$, but could easily double the consumer price index increase.

Apart from librarians' well-documented concerns about the consequences of "privatization" (submission for publication to for-profit publishers, which consistently charge higher per-unit rates for information than the not-for-profit sector) of research articles and many librarians' campaigns for detailed consumer information, it is useful to consider global, underlying factors of serial price increases, which are beyond the ability of scholars and librarians to resolve. One of these factors is the "equalization" of the United States among other nations or regions-the European Community, the Pacific Rim countries, and perhaps the Eastern Bloc. Rather than being preeminent in many endeavors, the U.S. is becoming one of several powerful co-players. One window on the dilution of influence is the publication of articles in key science journals.

\section{Serial subscription agen- cies have predicted $20 \%$ price increases for 1991. Hindsight shows these predictions to have been optimistic.}

Science Watch, a publication of ISI (Philadelphia), regularly reports international data about research sources and articles. Its sample issue reported that the Japanese have steadily increased their presence in organic superconducting over the past five years, producing $30.8 \%$ of the papers written in 1988 as opposed to $22.5 \%$ from the United States. A February 1990 article documented four fields where Japan leads and the United States lags. The May 1990 issue of Science Watch reported that Japanese scientists increased their presence in worldclass journals by $50 \%$ in 10 years. * The lead article, "For More Drugs, First Test is
Abroad," in the New York Times science section, August 7, 1990, reported that fewer clinical tests are done in the United States than Europe. That article cites a study earlier in 1990 by Dr. Thomas Stossel in the New England Joumal of Medicine tracking foreign publications in 10 years' worth of prestigious medical journals. Stossel concluded that the number of foreign papers in clinical research increased two to three times and those from the United States decreased similarly. Much of the shift is perceived to result from the "red tape" of doing such trials here. While none of the examples I have cited deal specifically with materials research, they are a sampling of what is happening in various fields of scientific research.

Another factor that affects domestic prices is the seeding of nationlike entities in the form of multinational companies. For competitiveness and efficiency, European and Japanese companies are establishing industries in the United States, while U.S. companies shift production to less expensive parts of the world. For example, Robert B. Reich of the Kennedy School of Government at Harvard University stated in an interview that $40 \%$ of IBM's employees are non-Americans. U.S. firms employ more than 100,000 workers in Singapore. Such trends are also present in cross-national, multisited publishing firms. Reich poses the increasing quandary as "Who is us?" Thomas Jefferson posed it as "Merchants have no country." In a recent New Yorker article (July 16, 1990) Richard J. Barnet suggested that if it fails to adopt a strategy of its own the United States will be living with policies fixed by organizations less and less accountable to those whose lives they affect.

Other "global" factors are the cost and complexities of some projects, particularly in the sciences, which require international collaboration and financing. Easy access to higher speed computing encourages scholars to work together on projects, without boundaries. The benefits are broader collegiality and quicker progress on many vexing human questions and problems. The drawbacks are, obviously, the large increase in research produced, its

*Editor's Note: An article in the December 1988 MRS BULLETIN, p. 7-12, analyzes the national origins of journal publications and conference papers in seven areas of materials research. See "Changing National Origins of Materials Research" by T.K. Devon and R. Roy, MRS BULLETIN, December 1988, p. 7-12. 
expense (particularly if produced abroad), and the resulting inability to afford, let alone access and read, what is produced. Thus, "globalization" of business and research is a phenomenon that introduces problems we have not learned to resolve or even tackle.

Ultimately, international perceptions powerfully affect a nation's economy and well-being. With their financial investments and political strategies, nations and corporations vote their confidence in other corporations and in entire nations. U.S. government policy and the declining perceptions of U.S. performance manifest themselves dramatically in unfavorable exchange rates, which exacerbate high prices for materials purchased from abroad.

Clearly, it is impossible for research institutions to sustain increases of over $20 \%$, a new level in the library materials pricing "crisis." The questions of "Should we care?" and "Is there a relationship between the extent of library resources and the quality of scientific research?" are asked from time to time, with the suggestion that the purchasing, servicing, and archiving of research reports and articles may, in fact, not be necessary to the discovery process. However, at least one preliminary study suggests that library resources correlate with academic research productivity.

Ann Okerson is director, Office of Scientific and Academic Publishing, Association of Research Libraries, Washington, DC.

\section{Available Through MRS}

\section{Proceedings of the} Industry-University Advanced Materials Conference II

Published by the

Advanced Materials Institute

Editor: F.W. Smith

1989, softcover, 98 papers, 888 pages

ISBN: 0-9624027-0.2

Order Code: AM-2B

\section{$\$ 40.00$ MRS Members $\$ 45.00$ U.S. List $\$ 50.00$ Foreign}

To order, call the MRS Publications Department at (412) 367-3012; fax (412) 367-4373.

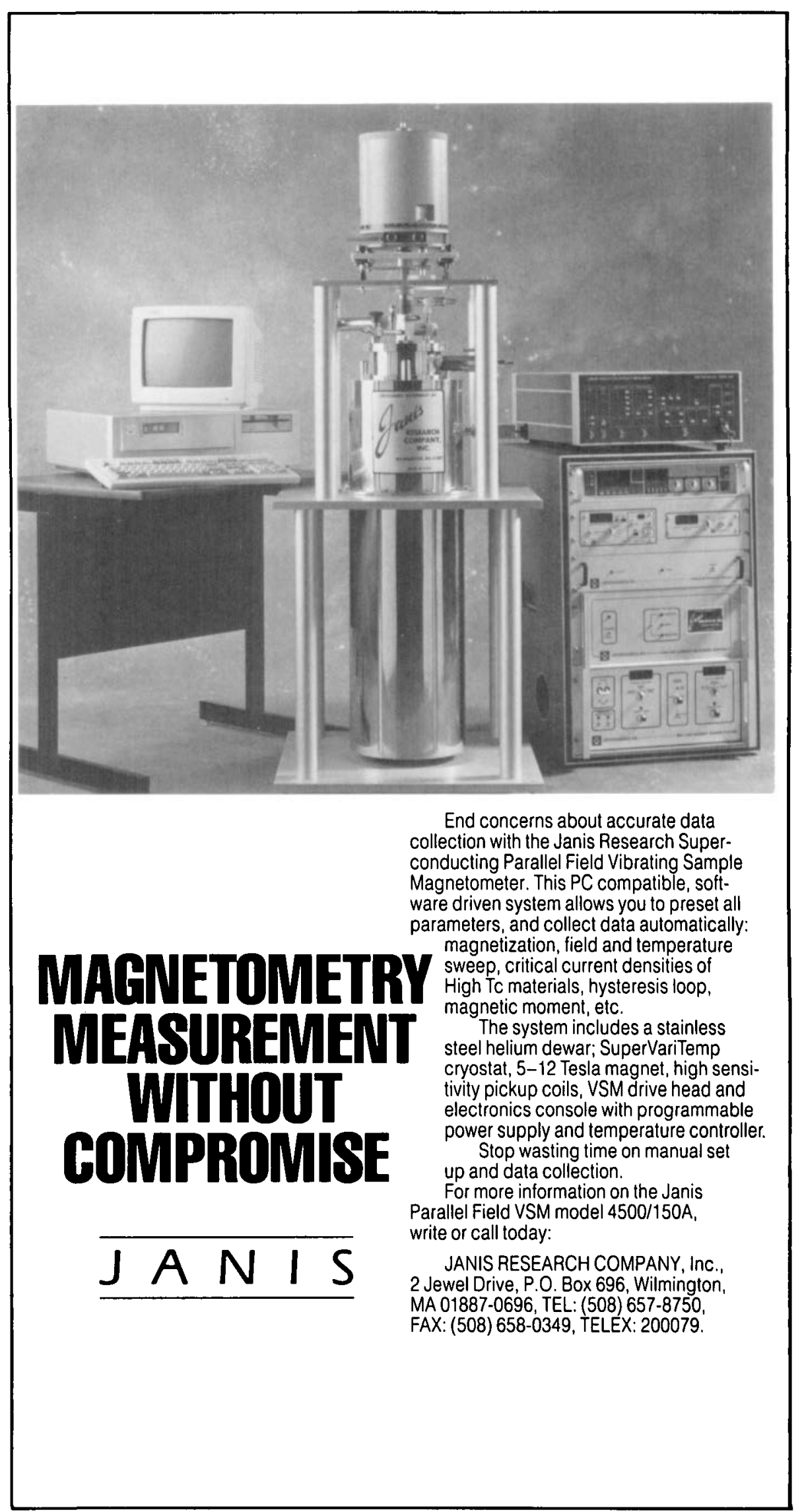

